\title{
Toward a More Expansive Discourse in a Changing World: An Analysis of Political Leaders' Speeches on Biodiversity
}

\author{
Sang Hun Lee ${ }^{1}$, Yi Hyun Kang ${ }^{2, * \mathbb{D}}$ and Rong Dai ${ }^{3}$ \\ 1 Korea Environment Institute, Sejong 30147, Korea; sanghunlee@kei.re.kr \\ 2 Bavarian School of Public Policy, Technical University of Munich, 80333 Munich, Germany \\ 3 Nanjing Institute of Environmental Sciences, Ministry of Ecology and Environment of the People's Republic \\ of China, Nanjing 210042, China; dairong@nies.org \\ * Correspondence: sealovei@gmail.com
}

Citation: Lee, S.H.; Kang, Y.H.;

Dai, R. Toward a More Expansive

Discourse in a Changing World: An

Analysis of Political Leaders'

Speeches on Biodiversity.

Sustainability 2021, 13, 2899.

https://doi.org/10.3390/

su13052899

Academic Editor: Alan Randall

Received: 16 February 2021

Accepted: 3 March 2021

Published: 8 March 2021

Publisher's Note: MDPI stays neutral with regard to jurisdictional claims in published maps and institutional affiliations.

Copyright: (c) 2021 by the authors. Licensee MDPI, Basel, Switzerland. This article is an open access article distributed under the terms and conditions of the Creative Commons Attribution (CC BY) license (https:// creativecommons.org/licenses/by/ $4.0 /)$.

\begin{abstract}
Speeches delivered in the Conference of the Parties (COPs) to the Convention on Biological Diversity represent leading discourses about biodiversity conservation. The discourse shared by high-level politicians is especially influential in the financing and decision-making process of global biodiversity governance. However, the speeches given in the COPs have not been the subject of systematic analyses until now. This study analyzes the host countries' speeches given at the six most recent COPs and investigates which discourses have been expressed in the speeches. The regulatory discourse that views nature as a resource was found to be the dominant discourse, while other discourses that view nature as a scientific object or a spiritual entity were represented only marginally. As the need for a transformational policy for biodiversity conservation is growing amid a global pandemic, it is essential to deepen our understanding of the dynamics and complexity of nature and reflect it in the policy process. This study suggests that more balanced discourse on biodiversity may earn broader audiences' consensus on biodiversity conservation.
\end{abstract}

Keywords: biodiversity; CBD; COP; discourse; high-level segment; political leader; speech

\section{Introduction}

Since its signing in 1992 at the Earth Summit in Rio de Janeiro, the Convention on Biological Diversity (CBD) has been among the most important international conventions related to the environment. With 196 parties as of 2020, the Conference of the Parties (COP) to the CBD has served as the central forum on global biodiversity policy. As the governing body, the COP reviews and steers the implementation of the convention. Representatives from the parties, non-party states, intergovernmental and non-governmental organizations, indigenous peoples and local communities, youth groups, academia, and the private sector participate in COP meetings and its subsidiary events.

The host country plays the role of mediator as well as setting the agenda for COP meetings. It establishes the theme of the COP meeting in consultation with the CBD secretariat. In addition, the host country often assumes the Presidency of the COP for two years until the next meeting, reviewing the provisional meeting agenda prepared by the CBD secretariat and leading discussions between the parties [1,2]. Therefore, the perspectives of COP hosting countries are significantly influential in global biodiversity discussions.

Among national actors involved in negotiation processes, the significance of highlevel officials, ministers, and heads of states needs to be noted. Their participation often raises the political authority of the negotiations. At the CBD COP-9 in 2008, for example, Angela Merkel, the Chancellor of Germany, announced the LifeWeb Initiative to facilitate funding for protected areas and invited other countries to join. This prompted the participation of several other countries, including Austria and Spain, in providing financial support for projects under this initiative. 
Since the first CBD COP in 1994, high-level segment (HLS) meetings organized by the host countries have been an important venue for high-level officials to engage in international biodiversity negotiations. While the HLS is not a part of the decision-making process of the COP, it has influenced negotiations during the COPs. For example, the CBD Working Group on access and benefit-sharing (ABS) had not reached an agreement on the ABS protocol during COP-10 until the last plenary meeting, the HLS meeting held at the last minute enabled the adoption of the protocol [3].

Despite its importance within the CBD, the HLS has not been a subject of scientific investigation in the environmental policy field previously. While political leaders play a critical role in global biodiversity governance, there has been little analysis of discourses that reflect their perspectives. Such a knowledge gap is problematic, given that discourse wields substantial power in the environmental policy-making process $[4,5]$. This paper attempts to fill this gap by focusing on the following research questions: Which frames and narratives are adopted for speeches on biodiversity? Why are certain discourses on biodiversity presented more frequently than others?

The relevance of discourse within environmental politics is evidenced by the surging number of discourse studies on environmental policy analysis in parallel with the growth of environmental policy over the last three decades [6-11]. Nevertheless, the number of studies on biodiversity discourse is surprisingly low, aside from a couple of studies that delved into how biodiversity became a political discourse $[12,13]$ and how ecosystem service and "counting and mapping" have dominated the international discussion of biodiversity [14]. Studies on how discourses are used for national biodiversity policies exist [15-17], but those studies do not explain discursive dynamics at the international level.

The central aim of this paper is to identify discourses used by heads of host countries in their speeches given in CBD COPs from 2008 to 2018. Through their statements, political leaders try to emphasize their contribution to global biodiversity conservation and provide direction to the ongoing negotiation. Discourses used in their speeches show the host country's understanding of global biodiversity conservation. Analyzing these speeches will, therefore, provide insights into the trend of global biodiversity discourses.

\section{Materials and Methods}

This paper follows an analytical framework model suggested by Herndl and Brown (1996) [18] that categorizes environmental discourse into three groups: Regulatory discourse that views nature as a resource to be managed for social welfare (ethnocentric), scientific discourse that views nature as an object for research (anthropocentric), and poetic discourse that views nature as a spiritual entity with intrinsic moral value (ecocentric). This "triad of centrism," as Marafiote and Plec (2006) [19] termed it, has been applied in research papers on environmental discourse analysis [19-21]. This model was chosen because it provides a useful framework to capture and classify the broad spectrum of biodiversity discourses. While there are studies that suggest different categories of environmental discourses, they are often too general to analyze biodiversity debates $[5,22]$ or too context-specific in certain circumstances $[16,23]$.

First, the regulatory discourse is usually found in institutions that have decisionmaking power on environmental regulations and policies [18]. This discourse views nature as a resource to manage for social welfare and it has been one of the "predominant views of nature" [20] (p. 42) in modern society, being in line with utilitarianism [18,20,22,24,25]. The fact that the main focus of this discourse is the utility of nature has made it powerful in the environmental policy-making process [18]. Recently, the narrative of this discourse has extended to ecosystem services and new conservation science (NCS). These perspectives seek the reason for conserving biodiversity and ecosystems from the services and economic values they provide [14,26-28]. Gustafsson (2013) [20] argues that the discourses of sustainable development and ecological modernization are in line with this discourse. Those discourses show the conviction that science and technology can manage environmental problems while maintaining economic (and social) growth [20,22]. 
The second discourse, scientific discourse, regards nature as an object for scientific research. It is based on the faith that humans can obtain knowledge of nature through scientific methodology. This discourse "subordinates nature to the human ability to scrutinize it" [20] (p. 43). Objective facts and logical reasoning are used for describing nature in order to build "knowledge" about it and scientific knowledge is regarded as the basis of the society-nature relationship [20]. This discourse represents a strong belief in the human ability to reveal nature's secret [18], and therefore, it shows the strongest tendency of nature/culture dualism, which has been pervasive in humanity [19].

Lastly, the poetic discourse finds mental and emotional values from nature. This discourse regards nature as a spiritual entity, which possesses intrinsic moral value [18,20,25,29]. Nature is distinct from human society and the untouched status of nature is regarded as as-it-should-be $[20,25]$. Humanity can live in harmony with nature when it realizes that society is a part of nature [18,20]. Herndl and Brown (1996) [18] point out that the power of this discourse comes from emotional appeals to the audience. The argument of the "Half Earth" approach, which proposes making half of the earth's surface into protected areas, takes this discourse [28,30].

Opening statements by the high-level officials of the host countries from COP-9 to COP-14 were selected for this analysis. The host countries of these COPs are Germany, Japan, India, Korea, Mexico, and Egypt. The selected COPs are the most recent ones and show the trends in discussions since the late 2000s. The opening statements were presented in the HLS meetings at the COPs except in Mexico, where the President of Mexico gave his opening speech in the plenary session [31] (p. 359).

The speeches were obtained from various sources: (a) Focal points of the host countries, (b) government websites, and (c) the CBD website [31-37]. While the statements were delivered in different languages, this paper used English-translated versions of the speeches.

The discourse analysis was undertaken in two steps. This was necessary because multiple forms of discourse can be found in one speech $[18,19]$. First, the contents of the statements were coded by topics that could be commonly found in the six speeches. These topics were identified during the coding process that was conducted in an inductive way [38]. We started open coding to examine the contents of the speeches without a given list of codes. Then, we grouped the codes by similar topics during axial coding, which led to the five topics: (1) Justification for conservation, (2) trust in institutional measures, (3) environmental justice, (4) financial support, and (5) description of nature. The first four are commonly addressed topics in COP meetings, and the last topic is often included in speeches to introduce host countries' tradition to value biodiversity. While there are subtle differences in the extent to which the countries presented these topics, these five provide an overview of the discourses that emerged in international biodiversity discussions. The codes obtained from the initial coding were then analyzed through the conceptual framework for biodiversity drawn from Herndl and Brown (1996) [18].

\section{Results}

The five topics found over the coding process were linked to the three categories of discourse: Nature as a resource, nature as an object, nature as a spirit (Figure 1). The first, justification for conservation, encompasses explicitly mentioned reasons for conservation. It can theoretically be related to any of the three Herndl and Brown (1996) [18] categories, as people can support conservation of biodiversity as a resource, an object for knowledge, or a spiritual entity. However, it was found that justification in the six speeches related mostly to the perspective of viewing nature as a resource. Trust in institutional measures, environmental justice, and financial support were related to the regulatory discourse because the goal of these three topics is to enhance human welfare through policies. Description of nature could be linked to all three perspectives, but in these six speeches, descriptions were presented under the scientific discourse and the poetic discourse. 


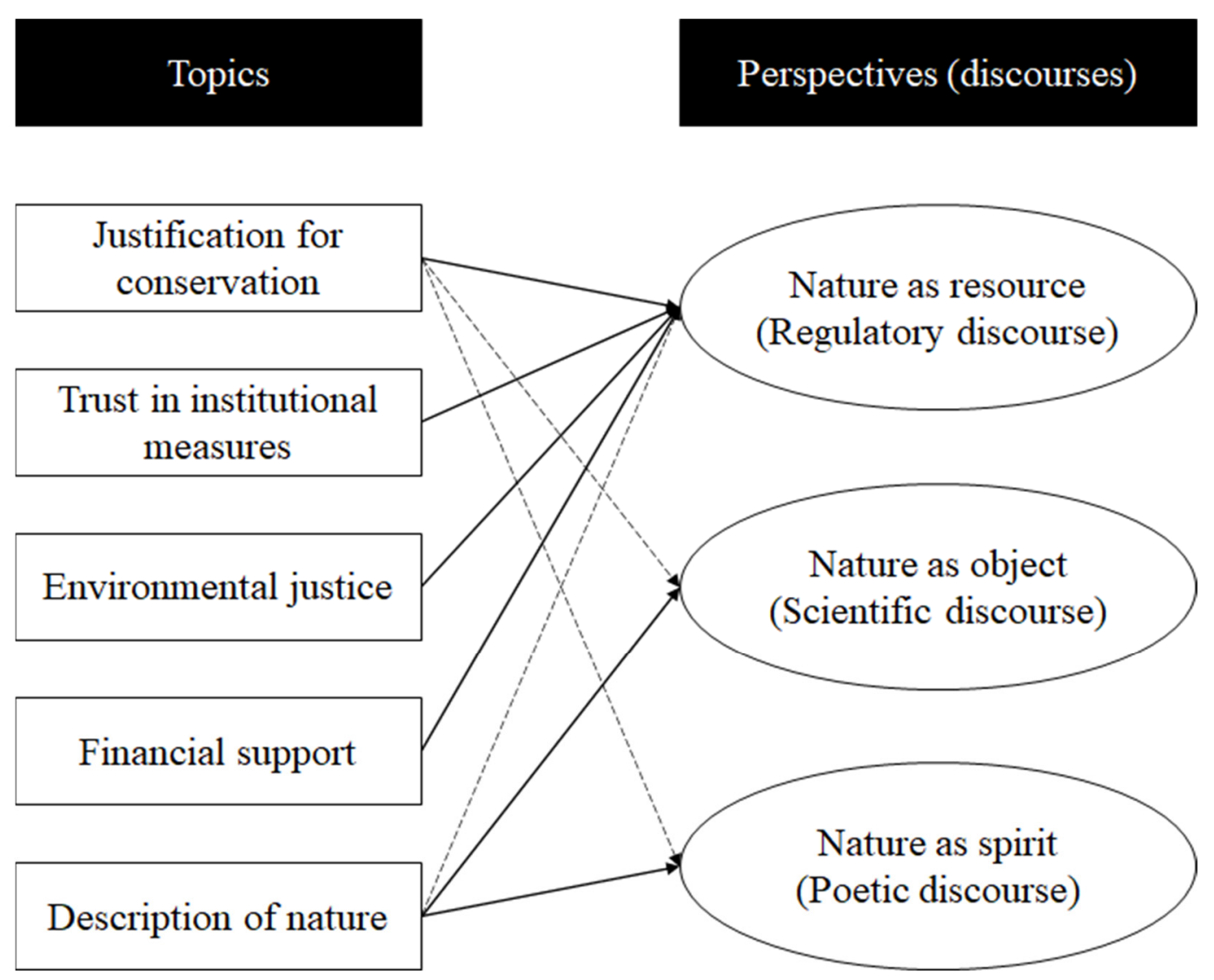

Figure 1. Relationships between topics and discourses in this study. Solid lines indicate relationships presented in the investigated speeches, and dashed lines suggest possible relationships in theory.

\subsection{Justification for Conservation}

The first topic, the necessity for biodiversity conservation, was underscored in all six speeches. The importance of biodiversity as a natural resource was the primary reason for conservation given in the statements. Commonly mentioned contributions of biodiversity to humanity included the provision of food (Germany, India, and Korea), energy (Korea and Egypt), and medicine (Germany, Japan, and India), regulation of climate change and other extreme weather events (Germany and India), and a tool for sustainable development (Korea, Mexico, and Egypt) (Table 1). Notably, Egypt devoted much of its speech to emphasizing the integration of biodiversity value in other development sectors for achieving sustainable development. As Egypt's Vision 2030 "adopted the concept of sustainable development as a general framework," the Prime Minister of Egypt mentioned that: 
Table 1. Contents in speeches in five topic categories.

\begin{tabular}{|c|c|c|c|c|c|c|}
\hline Category & COP-9 (Germany) & COP-10 (Japan) & COP-11 (India) & COP-12 (Korea) & COP-13 (Mexico) & COP-14 (Egypt) \\
\hline Justification for conservation & $\begin{array}{ll}\text { - } & \text { For humanity } \\
\text { - } & \text { Medicine } \\
\text { - } & \text { Cood } \\
& \text { Climate change }\end{array}$ & - $\quad$ Medicine & $\begin{array}{ll}\bullet & \text { Food } \\
\bullet & \text { Medicine } \\
- & \text { Extreme weather }\end{array}$ & $\begin{array}{ll}\text { - } & \text { For humanity } \\
\text { - } & \text { Sustainable } \\
\text { development } \\
\text { - } & \text { Food } \\
- & \text { Energy } \\
\text { - } & \text { Climate change }\end{array}$ & $\begin{array}{ll}\text { - } & \begin{array}{l}\text { Sustainable } \\
\text { development }\end{array} \\
\text { - } & \text { Tourism } \\
\text { - } & \text { Export }\end{array}$ & $\begin{array}{ll}- & \text { Sustainable } \\
& \text { development } \\
\text { - } & \text { Energy } \\
\text { - } & \text { Mining } \\
\text { - } & \text { Infrastructure } \\
\text { - } & \text { Health }\end{array}$ \\
\hline Trust in institutions & $\begin{array}{ll}- & \text { UN system } \\
\text { - International } \\
\text { certificate and } \\
\text { standard } \\
\text { - } \\
\text { Economic instruments } \\
\text { (auctioning, certificates) }\end{array}$ & $\begin{array}{ll}\text { - } & \text { UN system (UN } \\
& \text { Decade of } \\
& \text { Biodiversity) } \\
\text { - } & \text { Protocol on ABS }\end{array}$ & $\begin{array}{l}\text { India's Acts and programs } \\
\text { on biodiversity }\end{array}$ & - $\quad$ Nagoya Protocol & $\begin{array}{ll}\text { - } & \text { Payment for } \\
\text { ecosystem services } \\
\text { - } \quad \text { Protected areas and } \\
\text { safeguard zones }\end{array}$ & 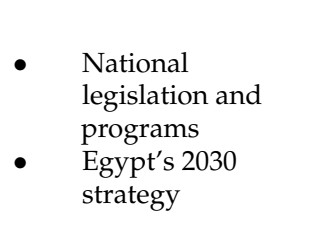 \\
\hline Financial support & $\begin{array}{ll}- & \text { LifeWeb Initiative } \\
- & \text { Pledge to provide } \\
& \text { financial resources }\end{array}$ & $\begin{array}{ll}\text { - } & \text { Life in Harmony } \\
\text { Initiative } \\
\text { - } & \text { Satoyama } \\
\text { Initiative }\end{array}$ & $\begin{array}{ll}\text { - } & \text { Mahatma Ghandi Scheme } \\
\text { (domestic) } \\
\text { - } & \text { Hyderabad Pledge } \\
\text { (domestic) } \\
\text { - } \quad \begin{array}{l}\text { Earmarked funds for } \\
\text { developing countries }\end{array}\end{array}$ & $\begin{array}{ll}\text { - } & \text { BioBridge Initiative } \\
\text { - } & \text { Forest Ecosystem } \\
\text { - } & \text { Restoration Initiative } \\
\text { Sustainable Ocean } \\
\text { Initiative }\end{array}$ & & \\
\hline Environmental justice & $\begin{array}{l}\text { Balance between } \\
\text { developed and } \\
\text { developing countries } \\
\text { Responsibility for } \\
\text { future generations }\end{array}$ & $\begin{array}{ll}\text { - } & \text { Responsibility for } \\
& \text { future generations }\end{array}$ & $\begin{array}{l}\text { - Traditional knowledge for } \\
\text { all humankind } \\
\text { - } \quad \text { Rights of farmers, forest } \\
\text { dwellers, and fishermen } \\
\text { - Care for the poor }\end{array}$ & $\begin{array}{l}\text { Responsibility for } \\
\text { future generations } \\
\text { Building links } \\
\text { between developed } \\
\text { and developing } \\
\text { countries }\end{array}$ & $\begin{array}{l}\text { - Well-being of present } \\
\text { and future generations }\end{array}$ & $\begin{array}{ll}\text { - } & \text { Natural reserves } \\
\text { managed by } \\
\text { youth and women } \\
\text { Rights of future } \\
\text { generations }\end{array}$ \\
\hline Description of nature & $\begin{array}{l}\text { Learning from nature } \\
\text { (firefly) }\end{array}$ & $\begin{array}{l}\text { - Creation of life on } \\
\text { earth } \\
\text { - } \quad \text { Living in harmony } \\
\text { with nature }\end{array}$ & $\begin{array}{l}\text { - } \quad \text { Sacred groves } \\
\text { Biodiversity as the } \\
\text { culmination of the } \\
\text { productive genius of } \\
\text { nature }\end{array}$ & $\begin{array}{l}\text { Life of harmony and } \\
\text { balance between } \\
\text { human and nature }\end{array}$ & $\begin{array}{l}\text { - Mayan's deep } \\
\text { material and spiritual } \\
\text { relationship } \\
\text { with nature }\end{array}$ & \\
\hline
\end{tabular}


"The process of integrating/generalizing biological diversity in these [energy, mining, infrastructure, industry, and health] sectors must take place through a comprehensive and conscious way of the value and importance of maintaining and managing biological diversity in a sustainable manner, with the participation of all sectors and related groups, civil society, women, and youth." [32].

The fact that all speeches sought reasons to conserve biodiversity for the benefits to humanity shows that the regulatory discourse to view nature as a resource might be a dominant discourse in the six countries.

\subsection{Trust in Institutional Measures}

The six countries showed their trust in institutions. Germany, Japan, and Korea stressed the achievements and progress accomplished under the UN system, such as the UN Decade of Biodiversity and the Nagoya Protocol. For example, the Chancellor of Germany stated:

"Only the United Nations can provide a reliable framework for this [national and international alliances between science, politics, business, and the people]. Within this framework, of course, the individual signatory states are then called upon to act." [35].

All countries pointed to their efforts to establish international and domestic instruments that aim to improve biodiversity conservation. Examples of these institutional instruments are auctioning and certificates for biodiversity (Germany), national legislations and programs (India, Mexico, and Egypt), and international initiatives (Germany, Japan, and Korea). Trust in institutional measures is a corollary of the regulatory discourse.

\subsection{Environmental Justice}

Environmental justice was an important topic in most speeches. Environmental justice can be regarded as a form of regulatory discourse. Even though the concept of environmental justice was not consistent, it emerged to address inequality among different groups of people [39]. Environmental justice is often understood in the economic and political context, pursuing the fair treatment of all people regarding environmental issues, such as access to environmental resources and mitigation of threats of natural risks [39,40]. In the speeches investigated in this paper, Germany, Japan, Korea, Mexico, and Egypt stressed the responsibility of the present generation to conserve biodiversity for future generations (Table 1). Intragenerational justice was also mentioned by some countries, indicating the need for balance between developing and developed countries (Germany and Korea) and among different social groups (India and Egypt).

\subsection{Financial Support}

Fourth, financial support for biodiversity conservation was mentioned in four speeches (Germany, Japan, India, and Korea) in the form of pledges to international or domestic initiatives and programs for capacity building. This is based on the belief that financial instruments can contribute to solving the problems of biodiversity loss and also on the responsibility of developed countries to help developing countries. Initiatives such as LifeWeb Initiative, Satoyama Initiative, and BioBridge Initiative were proposed during speeches by Germany, Japan, and Korea, respectively, which are all developed countries. All three initiatives target provision of resources to build capacity in developing countries.

One interesting pattern found in the second (trust in institutions) and fourth (financial support) topics is that developed countries proposed international institutions while developing countries mostly focused on domestic instruments during their speeches. This finding reflects the disparities between developed and developing countries in terms of financial resources for international instruments.

\subsection{Description of Nature}

Fifth, ecological knowledge and perspectives on nature were presented in all speeches except Egypt's. Interestingly, descriptions of nature varied more among the countries than 
the other four topics had. For example, Germany and Japan viewed nature as a repository of scientific knowledge by exemplifying the energy use of fireflies and the creation of biodiversity:

"Nature is a fabulous teacher. We have learned a lot from her, but she still has countless secrets that we can unravel. For example, how does the firefly manage to use energy with an impressive efficiency of 90 percent? Nature contains the empirical knowledge that has been proven and developed over thousands and sometimes millions of years." [35].

"When the earth was formed about 4.5 billion years ago, no life existed on this planet. Its distance from the sun kept temperature modest, and the existence of water, carbon dioxide, and a variety of other factors made possible the production of organic compounds from minerals, and four billion years ago, the very first manifestation of life appeared. Thereafter, that life was configured into various forms and extended to various parts of the earth. Planet earth in its current form, with its abundant plants and animals, was created from a grand coincidence of pivotal events in the universe." [34].

Meanwhile, the poetic discourse to position humans in a harmonious relationship with nature was discussed in the speeches of Japan, Korea, and Mexico. India also sees nature as a spiritual and sacred entity that regulates the balance of nature:

"The diversity of life forms on Earth is the culmination of millions of years of the productive genius of nature. It is nature's insurance against extreme events that may disturb the delicate balance of this planet." [37].

\section{Discussion}

Results from this discourse analysis of the speeches of CBD COP host countries show that the regulatory discourse viewing nature as resources was dominant among the host countries. Other discourses (viewing nature as an object of knowledge and as an ethical entity) were found only marginally. Figure 2 illustrates the proportions of each country's statements allocated to each discourse category.

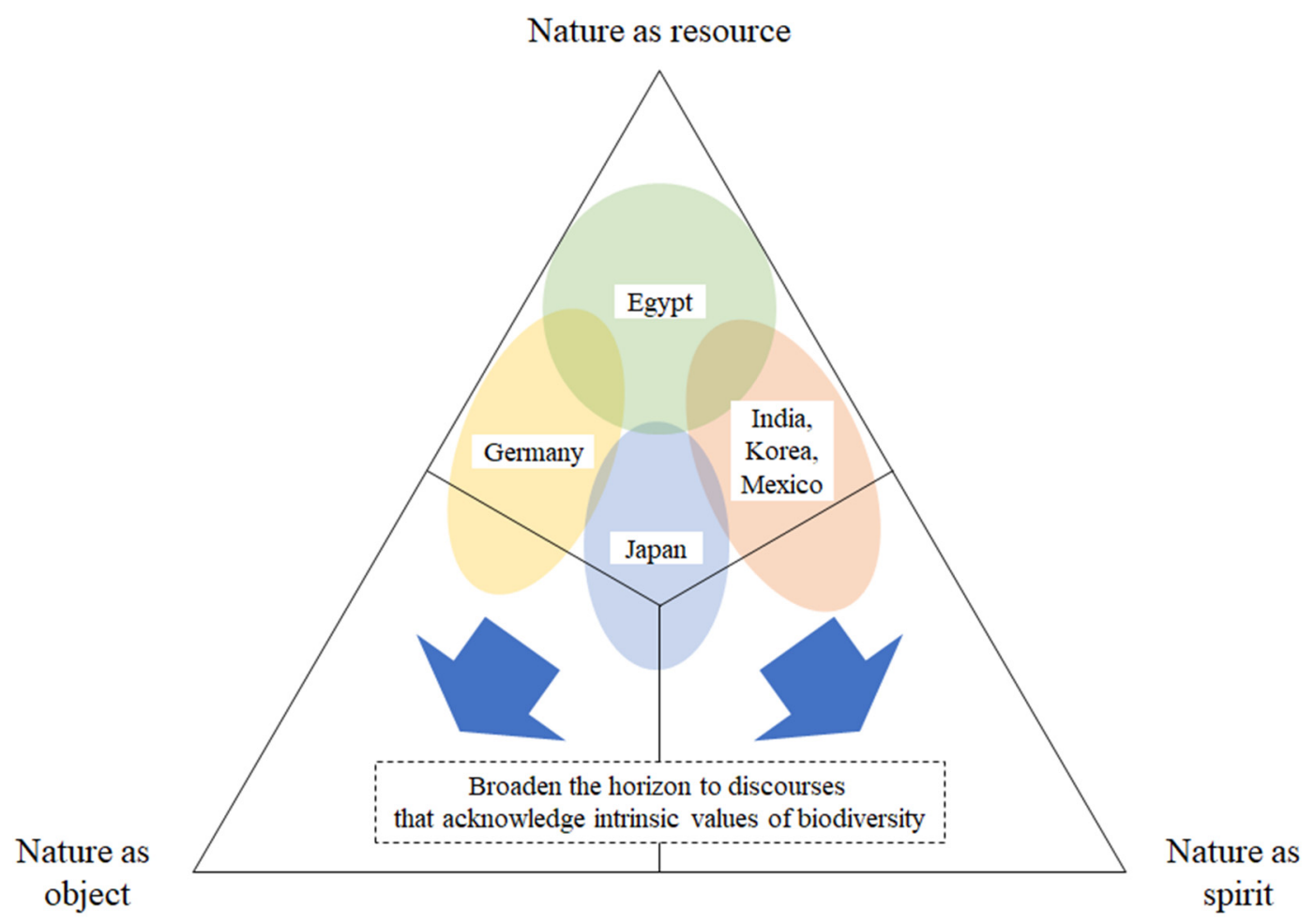

Figure 2. Perspectives in six speeches plotted on a biodiversity discourse triangle. The relative size of ellipses does not exactly reflect the actual proportions. 
One of the reasons the regulatory discourse is prevalent in high-level politics can be found in the increased presence of international institutions within global environmental governance. Environmental problems have become more complex than ever, and many of them are global in scale [41,42]. Coping with global environmental problems has triggered an inescapable need to facilitate cooperation and collective action among nation states and other relevant actors. As a result, a variety of actors, including national governments, multilateral institutions, multinational corporations, and non-governmental organizations, have gathered through international institutions, such as multilateral environmental agreements [42].

In addition, the regulatory discourse has been widespread across the world in relation to sustainable development, which takes the narrative of "nature as resources" for development $[20,26]$. Following the introduction of the best-known concept of sustainable development to the UN in 1987 [43], sustainable development has been continuously recognized in major UN summits (i.e., the UN Conference on Environment and Development 1992, the World Summit on Sustainable Development 2002, and the UN Conference on Sustainable Development 2012). This trend culminated in 2015 when sustainable development became the UN's manifest agenda until 2030 upon adopting 17 sustainable development goals (SDGs).

When the concept of ecosystem service became widespread in the mid-2000s, the reason for conserving biodiversity and ecosystems was sought among their services and the economic value they provide $[14,26,27]$. However, this regulatory discourse does not fully acknowledge the relationship between society, the environment, and the economy. The increasing threat to human health of newly-emerging infectious diseases requires a transformational policy for biodiversity through a deeper understanding of the dynamics and complexity of nature. One Health approach, for example, seeking the convergence of human, animal, and environmental health through scientific knowledge-a scientific discourse-might play a critical role in securing health for all, as well as conserving biodiversity [44,45]. Meanwhile, there is empirical evidence that spiritual perspectives on nature, along with tradition and religion, can contribute to protecting forests and their inhabiting species [46,47]. Revisiting the intrinsic value of biodiversity and ecosystems can help us recover the richness of human relationships with nature [14,27]. Thus, there is a need to broaden the horizon to include other discourses as well that acknowledge the intrinsic values of biodiversity (Figure 2).

China, the host country of the upcoming CBD COP meeting in 2021, holds a unique position in global biodiversity conservation. As one of 17 megadiverse countries with high numbers of species, the Chinese government has shown its pro-conservation efforts, such as the Green Shield project that aims to strengthen the protection of biodiversity in situ [48,49]. In addition, China has set up a national plan to build an "ecological civilization" that promotes living in harmony with nature [48]. This vision will be discussed in an international setting for the first time at the upcoming CBD COP to be held in Kunming. If during the COP, China can share lessons learned from its conservation policy implementation as well as its tradition of respecting and enshrining nature as a spiritual entity through speeches and activities, it may create momentum for the international community to expand the discourse of biodiversity conservation. Furthermore, it is worth noting that messages in political leaders' speeches given at international conferences often substantially influence their domestic politics.

The importance of biodiversity is being recognized more than ever around the world in the context of the COVID-19 pandemic. As the threat of new diseases increases when the environment is degraded, this pandemic may potentially reinforce our efforts to conserve biodiversity [50]. While the power of the "nature as a resource" discourse is undeniable in modern society, this discourse has exposed certain limitations to biodiversity conservation. Speeches that deliver a more balanced perspective that views nature as more than just a resource may inspire broader audiences. This paper provides a useful suggestion for political leaders who will participate in the upcoming biodiversity conference, based on the analysis of previous speeches in the CBD COP meetings. 
Author Contributions: Conceptualization, S.H.L., Y.H.K. and R.D.; methodology, S.H.L.; validation, Y.H.K.; formal analysis, S.H.L. and Y.H.K.; investigation, S.H.L.; data curation, Y.H.K.; writingoriginal draft preparation, S.H.L. and Y.H.K.; writing-review and editing, R.D.; visualization, S.H.L.; supervision, S.H.L.; project administration, Y.H.K.; funding acquisition, R.D. All authors have read and agreed to the published version of the manuscript.

Funding: This work was supported by the Biodiversity Investigation, Observation and Assessment Program of Ministry of Ecology and Environment of China (2019-2023) and the Natural Science Foundation of Jiangsu Province, China (Grant No. BK20160103).

Acknowledgments: The authors are grateful to Hyun-Woo Lee at Korea Environment Institute for his support to this article through advising on and reviewing the early version. We appreciate Camila Zepeda Lizama at the Secretariat of Foreign Affairs of Mexico for providing research data.

Conflicts of Interest: The authors declare no conflict of interest. The funders had no role in the design of the study; in the collection, analyses, or interpretation of data; in the writing of the manuscript, or in the decision to publish the results.

\section{References}

1. Convention on Biological Diversity. Decision Adopted by the Conference of the Parties to the Convention on Biological Diversity at Its First Meeting: I/1. Rules of Procedure for the Conference of the Parties; Convention on Biological Diversity: Nassau, Bahamas, 1994.

2. Convention on Biological Diversity. Decision adopted by the Conference of the Parties to the Convention on Biological Diversity at its fifth meeting: V/20. Operations of the Convention; Convention on Biological Diversity: Nairobi, Kenya, 2000.

3. Herkenrath, P.; Harrison, J. The 10th meeting of the Conference of the Parties to the Convention on Biological Diversity-a breakthrough for biodiversity? Oryx 2011, 45, 1-2. [CrossRef]

4. Hajer, M.; Versteeg, W. A decade of discourse analysis of environmental politics: Achievements, challenges, perspectives. J. Environ. Policy Plan. 2005, 7, 175-184. [CrossRef]

5. Hannigan, J. Environmental Sociology, 2nd ed.; Routledge: London, UK; New York, NY, USA, 2006; ISBN 9780415355124.

6. Fischer, F. Reframing Public Policy: Discursive Politics and Deliberative Practices; Oxford University Press: Oxford, UK, 2003; ISBN 9780199242641.

7. Hajer, M. Discourse Coalitions and the Institutionalization of Practice: The Case of Acid Rain in Britain. In The Argumentative Turn in Policy Analysis and Planning; Fischer, F., Forester, J., Eds.; UCL: London, UK, 1993; pp. 43-76.

8. Feindt, P.H.; Oels, A. Does discourse matter? Discourse analysis in environmental policy making. J. Environ. Policy Plan. 2005, 7, 161-173. [CrossRef]

9. Leipold, S.; Feindt, P.H.; Winkel, G.; Keller, R. Discourse analysis of environmental policy revisited: Traditions, trends, perspectives. J. Environ. Policy Plan. 2019, 21, 445-463. [CrossRef]

10. Hussein, H. Yarmouk, Jordan, and Disi basins: Examining the impact of the discourse of water scarcity in Jordan on transboundary water governance. Mediterr. Polit. 2019, 24, 269-289. [CrossRef]

11. Hussein, H. A critique of water scarcity discourses in educational policy and textbooks in Jordan. J. Environ. Educ. 2018, 49, 260-271. [CrossRef]

12. Väliverronen, E. Biodiversity and the Power of Metaphor in Environmental Discourse. Sci. Stud. (St. Bonaventure) 1998, 11, 19-34.

13. Escobar, A. Whose Knowledge, Whose nature? Biodiversity, Conservation, and the Political Ecology of Social Movements. J. Polit. Ecol. 1998, 5, 53. [CrossRef]

14. Turnhout, E.; Waterton, C.; Neves, K.; Buizer, M. Rethinking biodiversity: From goods and services to "living with". Conserv. Lett. 2013, 6, 154-161. [CrossRef]

15. Carmen, E.; Watt, A.; Young, J. Arguing for biodiversity in practice: A case study from the UK. Biodivers. Conserv. 2018, 27, 1599-1617. [CrossRef]

16. Espinosa, C. Interpretive Affinities: The Constitutionalization of Rights of Nature, Pacha Mama, in Ecuador. J. Environ. Policy Plan. 2019, 21, 608-622. [CrossRef]

17. Durand, L.; Vázquez, L.B. Biodiversity conservation discourses. A case study on scientists and government authorities in Sierra de Huautla Biosphere Reserve, Mexico. Land Use Policy 2011, 28, 76-82. [CrossRef]

18. Herndl, C.G.; Brown, S.C. Introduction. In Green Culture: Environmental Rhetoric in Contemporary America; Herndl, C.G., Brown, S.C., Eds.; University of Wisconsin Press: Madison, WI, USA, 1996; pp. 3-20.

19. Marafiote, T.; Plec, E. From dualisms to dialogism: Hybridity in discourse about the natural world. In The Environmental Communication Yearbook, 3rd ed.; Depoe, S.P., Ed.; Routledge: New York, NY, USA, 2006; pp. 49-75.

20. Gustafsson, K.M. Environmental discourses and biodiversity: The construction of a storyline in understanding and managing an environmental issue. J. Integr. Environ. Sci. 2013, 10, 39-54. [CrossRef]

21. Schlenz, M. Greening "Gray Literature": Rhetorical Models for Environmental Discourses. In Technical Communication, Deliberative Rhetoric, and Environmental Discourse: Connections and Directions; Coppola, N., Coppola, N.W., Karis, B., Eds.; ATTW Contemporary Studies in Technical Communication; Ablex Publishing Corporation: Stamford, CT, USA, 2000; ISBN 9781567504804. 
22. Dryzek, J.S. The Politics of the Earth: Environmental Discourses; Oxford University Press: Oxford, UK; New York, NY, USA, 2005; ISBN 9780199277391.

23. Brulle, R.J. Environmental Discourse and Social Movement Organizations: A Historical and Rhetorical Perspective on the Development of U.S. Environmental Organizations. Sociol. Inq. 1996, 66, 58-83. [CrossRef]

24. Merchant, C. The Death of Nature: Women, Ecology, and the Scientific Revolution; G-Reference, Information and Interdisciplinary Subjects Series; HarperCollins: New York, NY, USA, 1990; ISBN 9780062505958.

25. van Koppen, C.S.A. Resource, Arcadia, Lifeworld. Nature Concepts in Environmental Sociology. Sociol. Rural. 2000, 40, 300-318. [CrossRef]

26. MacDonald, K.I. The devil is in the (bio)diversity: Private sector "engagement" and the restructuring of biodiversity conservation. Antipode 2010, 42, 513-550. [CrossRef]

27. Spash, C.L.; Aslaksen, I. Re-establishing an ecological discourse in the policy debate over how to value ecosystems and biodiversity. J. Environ. Manag. 2015, 159, 245-253. [CrossRef] [PubMed]

28. Gavin, M.; McCarter, J.; Berkes, F.; Mead, A.; Sterling, E.; Tang, R.; Turner, N. Effective Biodiversity Conservation Requires Dynamic, Pluralistic, Partnership-Based Approaches. Sustainability 2018, 10, 1846. [CrossRef]

29. Hannigan, J.A. Environmental Sociology: A Social Constructionist Perspective; Environment and society; Routledge: London, UK, 1995; ISBN 9780415112550.

30. Wilson, E.O. Half-Earth: Our Planet's Fight for Life; Norton \& Company: New York, NY, USA, 2016.

31. Convention on Biological Diversity. Report of the Conference of the Parties to the Convention on Biological Diversity on its Thirteenth Meeting; Convention on Biological Diversity: Cancun, Mexico, 2016.

32. Cabinet of Egypt The Prime Minister's Speech at the Opening of the Ministerial Meeting of the Fourteenth Conference of Parties to the Convention on Biological Diversity. Available online: http://www.cabinet.gov.eg/arabic/PrimeMinister/ SpeechesInterviews / (accessed on 20 January 2020).

33. Chung, H. The Message at the Opening Ceremony of the 12th Conference of Parties to the CBD. Available online: http:/ / www.opm.go.kr/opm/prime/past-speech.do? mode=view\&articleNo=9747 (accessed on 28 December 2019).

34. Kan, N. Address by H.E. Mr. Naoto Kan Prime Minister of Japan at the Opening of the High Level Segment of the Tenth Meeting of the Conference of Parties to the Convention on Biological Diversity. Available online: https://japan.kantei.go.jp/kan/ statement/201010/27speech_e.html (accessed on 31 July 2020).

35. Merkel, A. Rede von Bundeskanzlerin Dr. Angela Merkel. Available online: https://www.bundesregierung.de/breg-de/service/ bulletin/rede-von-bundeskanzlerin-dr-angela-merkel-796140 (accessed on 27 May 2020).

36. Secretariat of Environment and Natural Resources. United Nations Biodiversity Conference Presidency Report Mexico 2016-2018; Secretariat of Environment and Natural Resources: Mexico City, Mexico, 2018.

37. Singh, M. Remarks by the Prime Minister at the inauguration of the High Level Segment of the 11th Conference of Parties to the Convention on Biological Diversity. Available online: https:/ /www.cbd.int/doc/speech/2012/sp-2012-10-16-cop11-hls-in-pm-en.pdf (accessed on 31 July 2020).

38. Babbie, E. The Practice of Social Research; Cengage Learning: Belmont, CA, USA, 2009; ISBN 9780495598411.

39. Beretta, I. Some Highlights on the Concept of Environmental Justice and its Use. e-Cad. CES 2012, 136-162. [CrossRef]

40. Environment Protection Agency. Guidance for Incorporating Environmental Justice Concerns in EPA's NEPA Compliance Analyses; Environment Protection Agency: Washington, DC, USA, 1998.

41. Dunlap, R.E.; Jorgenson, A.K. Environmental problems. Wiley-Blackwell Encycl. Glob. 2012, 2, 519-540. [CrossRef]

42. Speth, J.G.; Haas, P.M. Global Environmental Governance; Island Press: Washington, DC, USA, 2006.

43. World Commission on Environment and Development. Our Common Future; Oxford University Press: Oxford, UK, 1987.

44. American Veterinary Medical Association. One health: A new professional imperative. In One Health Initiative Task Force: Final Report; American Medical Veterinary Association: Schaumburg, IL, USA, 2008; pp. 1-71.

45. Romanelli, C.; Cooper, H.D.; De Souza Dias, B.F. The integration of biodiversity into One Health. OIE Rev. Sci. Tech. 2014, 33, 487-496. [CrossRef]

46. Anthwal, A.; Gupta, N.; Sharma, A.; Anthwal, S.; Kim, K.H. Conserving biodiversity through traditional beliefs in sacred groves in Uttarakhand Himalaya, India. Resour. Conserv. Recycl. 2010, 54, 962-971. [CrossRef]

47. Virtanen, P. The Role of Customary Institutions in the Conservation of Biodiversity: Sacred Forests in Mozambique. Environ. Values 2016, 11, 227-241. [CrossRef]

48. Yang, R.; Peng, Q.; Cao, Y.; Zhong, L.; Hou, S.; Zhao, Z.; Huang, C. Transformative changes and paths toward biodiversity conservation in China. Biodivers. Sci. 2019, 27, 1032-1040. [CrossRef]

49. Zou, Y.; Fu, Y.; Yang, L.; Wan, X.; Wang, Y.; Liu, J. China and COP 15: A path for responsible environmental power. Biodivers. Sci. 2017, 25, 1169-1175. [CrossRef]

50. Pearson, R.M.; Sievers, M.; McClure, E.C.; Turschwell, M.P.; Connolly, R.M. COVID-19 recovery can benefit biodiversity. Science 2020, 368, 838-839. [PubMed] 